\title{
The Properties and Suitability of Various Biomass/Coal Blends for Co-Gasification Purposes
}

\author{
Sibongiseni Gaqa ${ }^{1,2}$, Sampson Mamphweli2 ${ }^{2}$ David Katwire', Edson Meyer ${ }^{2}$ \\ ${ }^{1}$ Chemistry Department, University of Fort Hare, Alice, South Africa \\ ${ }^{2}$ Institute of Technology, University of Fort Hare, Alice, South Africa \\ Email: sgaqa@ufh.ac.za, smamphweli@ufh.ac.za, dkatwire@ufh.ac.za, emever@ufh.ac.za
}

Received 22 June 2014; revised 23 July 2014; accepted 26 August 2014

Copyright (C) 2014 by authors and Scientific Research Publishing Inc.

This work is licensed under the Creative Commons Attribution International License (CC BY). http://creativecommons.org/licenses/by/4.0/

(c) (i) Open Access

\section{Abstract}

Gasification is a promising technology for the production of gaseous fuels, mainly syngas, which is produced from the hydrocarbon-based materials such as coal and biomass. Currently, coal is the main feedstock that is used for the gasification process due to its large reserves and higher energy per volume. However, the use of coal has been a more concern because of the environmental impacts caused by the emission of toxic gases such as the sulphides, sulphates and nitrates as well as the ash slagging problems forming inside the gasifier. On the other hand, biomass is a renewable energy resource of interest as a replacement for coal to reduce the environmental impacts associated with fossil fuel usage. Much consumption of fossil fuels has caused serious energy crisis and environmental impacts, globally. Co-gasification of coal and biomass is considered as a connection between energy production based on fossil fuels and energy production based on renewable fuels. The utilization of biomass by co-gasification with coal causes reductions of carbon dioxide, nitrogen and sulfur emissions due to the renewable character of biomass and low contamination content in biomass. This study determined the properties of various biomass/coal blends and their suitability for co-gasification in a downdraft biomass gasifier. A bomb calorimeter was used to determine the calorific values of the material. CHNS and XRF analysis were carried out to determine the elemental analysis of the material. Thermogravimetric analysis (TGA) was conducted to investigate the thermal degradation of the material. The kinetic analysis of the various feedstocks allows the prediction of the rate at which co-gasification takes place. The results suggested that blending coal with biomass result in a faster reaction rate at lower temperatures than that of coal alone and lower activation energy due to the high quantity of volatile matter in biomass.

\section{Keywords}

Gasification, Functional Groups, Thermochemical Process, Coal, Biomass 


\section{Introduction}

Energy plays an important role in the world's present and future. Global annual energy demand is constantly and rapidly growing. The best way of providing for this enormous increase is energy diversification, such as declining reserves and fluctuating prices of fossil fuels, national energy security, minimization of environmental impact given the increase in atmospheric carbon dioxide $\left(\mathrm{CO}_{2}\right)$, and lead to sustainable fuels. In this perspective biomass appears as an attractive resource, potentially to progressively replace fossil fuels [1]. The use of biomass as an alternative energy source can be traced back to the first wood-fuelled fire. However, biomass produces cleaner syngas than coal because of its lower sulphur and ash contents and neutral traces of carbon. There is also a greater degree of complexity involved in processing biomass before gasification starts [2]. Biomass is a world-wide available renewable energy resource. Biomass are a world-wide available renewable energy resource, when produced by sustainable means it removes just about the same amount of carbon dioxide during its energy conversion as that adsorbed by photosynthesis during plant life, as a result, the use of biomass does not contribute to the increase of $\mathrm{CO}_{2}$ in the atmosphere, and this makes it a remarkable energy source in the present context of environmental attention towards the emission levels of greenhouse gases [3]. During gasification, slight oxidation and major pyrolysis take place. During pyrolysis biomass/coal produces char condensable volatiles and tar, and gaseous products. Char is mostly carbon and it follows reactions 1 to 6 (below) during gasification:

Oxidation reaction

$$
\mathrm{C}+\mathrm{O}_{2} \leftrightarrow \mathrm{CO}_{2}(+393 \mathrm{MJ} / \mathrm{kg} / \mathrm{mole})
$$

Methanation reaction

$$
\mathrm{C}+2 \mathrm{H}_{2} \leftrightarrow \mathrm{CH}_{4}(+75 \mathrm{MJ} / \mathrm{kg} \text { mole })
$$

Water-gas shift reaction

$$
\mathrm{CO}+\mathrm{H}_{2} \mathrm{O} \leftrightarrow \mathrm{CO}_{2}+\mathrm{H}_{2}(+122.6 \mathrm{MJ} / \mathrm{kg} \text { mole })
$$

Steam reforming reaction

$$
\mathrm{H}_{2}+1 / 2 \mathrm{O}_{2} \leftrightarrow \mathrm{H}_{2} \mathrm{O}(+241.1 \mathrm{~kJ} / \mathrm{mol})
$$

Water gas reaction

$$
\mathrm{C}+\mathrm{H}_{2} \mathrm{O} \leftrightarrow \mathrm{CO}+\mathrm{H}_{2}(+42.3 \mathrm{MJ} / \mathrm{kg} / \text { mole })
$$

Boudouard reaction

$$
\mathrm{C}+\mathrm{CO}_{2} \leftrightarrow 2 \mathrm{CO}(-164.9 \mathrm{MJ} / \mathrm{kg} / \mathrm{mole})
$$

All of the volatiles and some tars are thermally broken down into simple gaseous products during gasification. The remaining tar and some other alkali minerals leave with the product gases [4]. A number of studies on the thermo chemical conversion of biomass or residues from wood products have been carried out. These studies revealed in principle a similar behaviour to that of coal. In general, a total gasification process can be generally separated into two main reaction stages called pyrolysis and gasification. The pyrolysis stage corresponds to actions related to devolatilization or thermal decomposition that occur during the initial heating-up of a solid fuel, and is completed only in seconds, or less at high temperatures [5]. Gasification begins with an endothermic process known as pyrolysis, where the small amount of carbon-based feedstock is burned; giving heat that is essential to drive out moisture and volatiles, and all this takes place in the absence or poor presence of oxygen. After pyrolysis, more heat is then needed to thermally break the volatiles and the long hydrocarbon chains into lighter gases. The remaining carbon left in the feedstock is then gasified giving syngas as the product. The chemical form of syngas usually consists mostly of $\mathrm{CO}, \mathrm{H}_{2}$ and $\mathrm{CH}_{4}$ as fuel and also $\mathrm{CO}_{2}, \mathrm{~N}_{2}$, and water vapour as non-combustible gases [2]. The syngas also consists of $\mathrm{H}_{2} \mathrm{~S}, \mathrm{COS}, \mathrm{HCN}, \mathrm{HCl}, \mathrm{Hg}$, and other contaminants that will have to be removed before utilizing the syngas for power generation. Unlike combustion, the aim of gasification is to produce syngas that can then be separated into components and used for different applications in a more efficient way. All of this occurs inside the gasifier. After the volatiles leave the feedstock, what is left in the gasifier is char, which is basically pure carbon. Once this occurs, then the char is reacted using air/oxygen and steam to produce carbon monoxide $(\mathrm{CO})$, carbon dioxide $\left(\mathrm{CO}_{2}\right)$, and hydrogen $\left(\mathrm{H}_{2}\right)$ [Long III and Wang, 2011]. Figure 1 shows the basic step wise processing for the co-gasification of coal and biomass: 


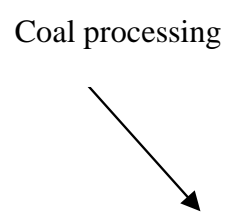

Biomass processing

Preparation of biomass /

coal blends

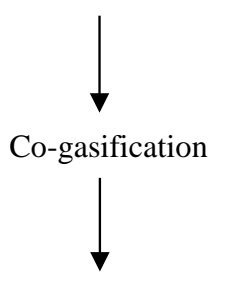

Gas cleanup

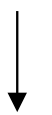

Gas utilization

Figure 1. Basic step wise processing for the co-gasification of coal and biomass.

\section{Materials and Methods}

Samples of eucalyptus and coal chips were used for this study. The cone-and-quaternary method was applied subsequent to size reduction to obtain more representative samples. Chips were milled using a Condux-Werk Wolfgang bei Hanau mill equipped with a $1 \mathrm{~mm}$ circular blade to reduce the size of the chips to approximately $\pm 425 \mu \mathrm{m}$, the chips were further milled to approximately $\pm 250 \mu \mathrm{m}$. To obtain the fractions between 250 and 425 $\mu \mathrm{m}$ the samples were screened in a Retsch AS200 shaker, where the $250 \mu \mathrm{m}$ was used for these analyses. For quantitative elemental analysis of the materials a CHNS and XRF analysers were used. Thermogravimetric Analyser (TGA) was used to observe the thermal degradation of the material. The methodology employed is outlined in Figure 2.

\section{Results and Discussion}

\subsection{Calorific Values}

Table 1 shows the energy values of coal, eucalyptus and the coal/eucalyptus blends. This data was obtained using ECO CAL-2K bomb calorimeter, to establish the relation when coal is blended with biomass, whether the energy values of the blends would decrease or increase since the good quality gas also depends on the energy values of the material used for the gas production

From Table 1 it was observed that the coal has a lower energy value of about $17.78 \mathrm{MJ} / \mathrm{kg}$ which is far less than the amount found in high grade coals of more than $24 \mathrm{MJ} / \mathrm{kg}$ [Ganesh, 2006], however this value is acceptable since it is more than $15 \mathrm{MJ} / \mathrm{kg}$ reported to be the lowest calorific value of low grade coal. The eucalyptus was observed to have the energy value of about $18 \mathrm{MJ} / \mathrm{kg}$, which is for a typical biomass Lignocellulosic material. The blends showed no significant difference between from the pure coal and pure eucalyptus wood. Although the calorific values of the materials did not differ significantly, the rate of thermal degradation and energy released was different due to the high carbon content in coal and the blends with higher carbon content. This is further discussed during the analysis of thermal degradation (TG).

\subsection{Proximate Analysis}

Table 2 presents the proximate analysis of coal, eucalyptus and the eucalyptus/coal blends.

According to Ganesh, 2006 a typical biomass material has volatile matter content in the range from $60 \%$ to $90 \%$ and a typical with coal having volatile matter ranging from $20 \%$ to $50 \%$. From Table 2 the volatile matter of the 


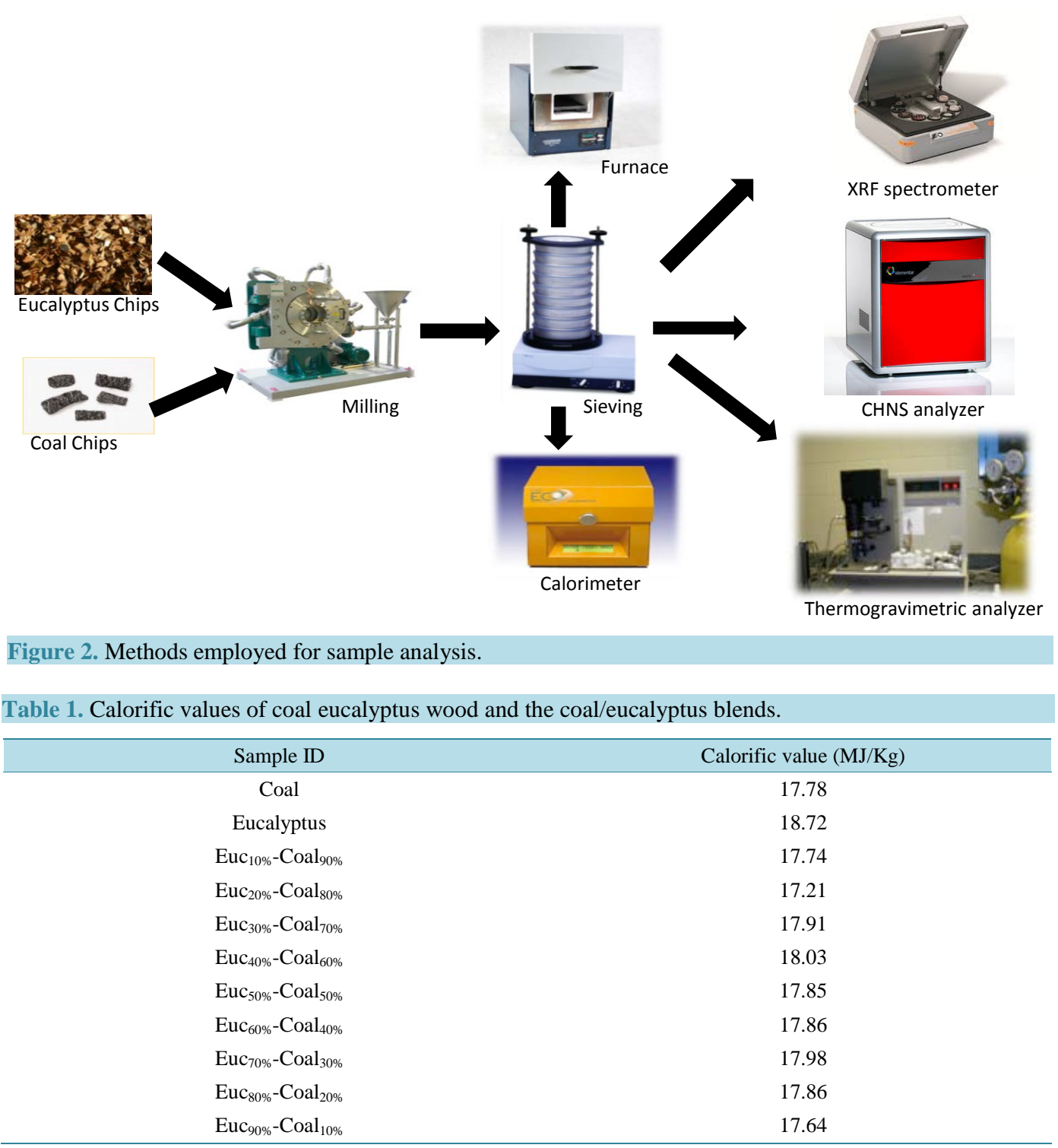

Euc: eucalyptus.

Table 2. Proximate analysis of coal, eucalyptus and the eucalyptus/coal blends.

\begin{tabular}{|c|c|c|c|}
\hline Sample ID & $\% \mathrm{VM}$ & $\% \mathrm{FC}$ & $\%$ Ash \\
\hline Coal & 24.27 & 25.94 & 47.48 \\
\hline Eucalyptus & 78.65 & 18.51 & 0.775 \\
\hline Euc $_{10 \%}-$ Coal $_{90 \%}$ & 23.31 & 23.96 & 42.50 \\
\hline Euc $_{20 \%}-$ Coal $_{80 \%}$ & 29.54 & 23.56 & 34.37 \\
\hline Euc $_{30 \%}-$-Coal $_{70 \%}$ & 37.54 & 22.00 & 35.28 \\
\hline Euc $_{40 \%}-$ Coal $_{60 \%}$ & 43.59 & 22.76 & 27.42 \\
\hline Euc $_{50 \%}-$-Coal $_{50 \%}$ & 50.48 & 20.52 & 20.78 \\
\hline Euc $_{60 \%}-$ Coal $_{40 \%}$ & 55.22 & 20.33 & 16.81 \\
\hline Euc $_{70 \%}-$ Coal $_{30 \%}$ & 61.63 & 19.83 & 13.59 \\
\hline Euc $_{80 \%}-$ Coal $_{20 \%}$ & 69.29 & 19.32 & 8.535 \\
\hline Euc $_{90 \%}-$ Coal $_{10 \%}$ & 74.32 & 18.53 & 6.599 \\
\hline
\end{tabular}

Euc: eucalyptus. 
coal used for this study is $24.27 \%$ and the volatile matter of the eucalyptus is $78.75 \%$, both these values are within the acceptable ranges. Generally the volatile matter is a mixture of short and long chain hydrocarbons, aromatic hydrocarbons and some sulfur. The bonds between these hydrocarbons are strong in coal and medium to light in the biomass materials, which explains the high volatile matter content in eucalyptus and low content in coal. It is also observed that the blends with the high content of coal have low volatile matter content and the blends with high eucalyptus content have high volatile matter content, which then implies that there is a synergy that exists between eucalyptus and coal during thermochemical conversion, and this synergy is further explained in the TGA section.

The fixed carbon content of a certain material is the carbon that is left after the volatiles have been driven off. It differs from the ultimate carbon content of the coal because some carbon is lost in hydrocarbons with the volatiles. The fixed-carbon value is one of the parameters used in conducting computer simulations. The percentage amount of ash also showed that the coal used for this study is a low grade coal with very high ash content of $47.73 \%$. The eucalyptus on the other hand has low ash content of $0.775 \%$. This implies that this type of coal is not good for gasification because it can cause blockages, slagging in the rector and excessive tar formation depending on its chemical composition. This high ash content in coal is also the reason for the low calorific value of the coal [6]. The blending of this type of coal with eucalyptus could thus lead to the low ash content in the blend and reduce some of the latter risks, blending this type of coal with eucalyptus reduces the ash content. The more eucalyptus added the lower the ash content. Adding 50\% eucalyptus to the coal reduces the ash from $42 \%$ to $20 \%$ implying a $50 \%$ decrease in ash content. It is well known that there is a correlation between the ash content and the calorific value of the fuel. Lower ash content should imply higher calorific value; however the results recorded in this study do not suggest a change in the calorific value after blending.

\subsection{Ultimate Analysis}

Table 3 presents the elemental analysis of coal, eucalyptus and the eucalyptus/coal blends. This data was obtained using a Vario EL CUBE CHNS analyzer.

Generally, compared with solid fossil fuels, biomass materials contain much less carbon content and more oxygen [7]. From Table 3 it can observed that the quantity of carbon in coal was found to be higher than that of eucalyptus as expected (about 55.90\%). The carbon content of all the eucalyptus/coal blends decreases with an increase in the quantity of eucalyptus in the blend. This is because of some dilution effect caused by the low carbon content in eucalyptus. This may have an impact on the energy value of the feedstock; however, it might not be a challenge as it may be complemented by the reactivity of eucalyptus that would act as a catalyst for full conversion of coal, thereby resulting in more energy released, this can be clearly observed when a high grade coal is used. During combustion sulphur quantitavely oxides and some of it reacts with alkali materials to form sulphates. Alkali sulphates are unstable at typical combustion temperatures of about $900^{\circ} \mathrm{C}$. These sulphates can stimulate agglomeration [6]. As can be observed from Table 3, both coal and eucalyptus result in blends with minimal amounts of sulphur.

Table 3. CHNS analysis of coal, eucalyptus and eucalyptus/coal blends.

\begin{tabular}{|c|c|c|c|c|c|}
\hline Sample ID & $\% \mathrm{C}$ & $\% \mathrm{H}$ & $\% \mathrm{~N}$ & $\% \mathrm{~S}$ & $\% \mathrm{O}$ \\
\hline Coal & 55.90 & 3.900 & 1.250 & 0.400 & 38.55 \\
\hline Eucalyptus & 45.30 & 5.500 & 0.070 & 1.000 & 48.13 \\
\hline Euc $_{10 \%}-$-Coal $_{90 \%}$ & 53.39 & 3.980 & 1.150 & 0.340 & 41.14 \\
\hline Euc $_{20 \%}-$-Coal $_{80 \%}$ & 53.01 & 4.100 & 1.120 & 0.398 & 41.37 \\
\hline Euc $_{30 \%}-$ Coal $_{70 \%}$ & 51.49 & 4.000 & 1.100 & 0.465 & 42.94 \\
\hline Euc $_{40 \%}-$ Coal $_{60 \%}$ & 52.26 & 4.250 & 0.980 & 0.473 & 42.04 \\
\hline Euc $_{50 \%}-$ Coal $_{50 \%}$ & 51.03 & 4.429 & 0.850 & 0.500 & 43.19 \\
\hline Euc $_{60 \%}-$-Coal $_{40 \%}$ & 49.69 & 4.320 & 0.543 & 0.702 & 44.74 \\
\hline Euc $_{70 \%}-$ Coal $_{30 \%}$ & 48.82 & 5.201 & 0.220 & 0.798 & 44.96 \\
\hline Euc $_{80 \%}-$ Coal $_{20 \%}$ & 47.55 & 4.730 & 0.099 & 0.990 & 46.63 \\
\hline Euc $_{90 \%}-$-Coal $_{10 \%}$ & 46.71 & 4.900 & 0.089 & 0.975 & 47.33 \\
\hline
\end{tabular}

Euc: eucalyptus. 


\subsection{TG and DTG Analysis}

Figure 3 and Figure 4 presents the mass loss and derivative mass loss of coal and eucalyptus with respect to temperature and time, respectively. The data was obtained by analysing the samples using Perkin Elmer TGA 4000. All samples were analyzed by purging with Nitrogen at a flow rate of $20 \mathrm{~mL} / \mathrm{min}$. All the samples were heated from $35^{\circ} \mathrm{C}$ to $900^{\circ} \mathrm{C}$ at $20^{\circ} \mathrm{C} / \mathrm{min}$. This data was necessary to establish the rate of thermal degradation of coal, eucalyptus and the eucalyptus/coal blends to obtain the basis for comparison of the data on the blends. Lignocellulosic biomass consists of cellulose, hemicellulose and lignin.

Cellulose is the major structural component of plants, especially of wood and plant fibres. It is a linear homogeneous polymer and degrades at higher temperatures (around $300^{\circ} \mathrm{C}-900^{\circ} \mathrm{C}$ ). Hemicellulose is a polysaccharide found in plant cell walls and it normally decomposes at temperatures above $160^{\circ} \mathrm{C}$ up to around $300^{\circ} \mathrm{C}$. Lignin is found in all vascular plants, and represents about $25 \%$ of the terrestrial plant biomass. It is a complex phenolic heteropolymer that results from oxidative polymerization [8]. It is normally lost at a slow rate over a wide temperature rate of $200^{\circ} \mathrm{C}-500^{\circ} \mathrm{C}$.

During thermal degradation (Figure 3 ) there were three most distinct stages that were observed. In the first stage (A) moisture is released followed by the release of the volatiles in the second stage of degradation (B) and then fixed carbon in the third stage of degradation $(\mathrm{C})$. The coal used had very low moisture content as compared to the biomass materials, but it was found to degrade very slowly due to the presence of long strong carbon - carbon chains as well as the aromatic rings as observed with FT-IR analysis. It was observed that eucalyptus degraded at lower temperatures due to the high quantity of volatile matter content in biomass materials as compared to coal. From the derivative weight loss graph which is Figure 4 it was observed that the rapiddevolatization of coal took place at higher temperature than that of eucalyptus, which was $530^{\circ} \mathrm{C}$ and $322^{\circ} \mathrm{C}$ respectively. This implies that coal requires higher gasification temperature than biomass for complete gasification to take place. Figure 5 and Figure 6 presents the mass loss and derivative mass loss of the eucalyptus/coal blends, respectively in relation to temperature and time.

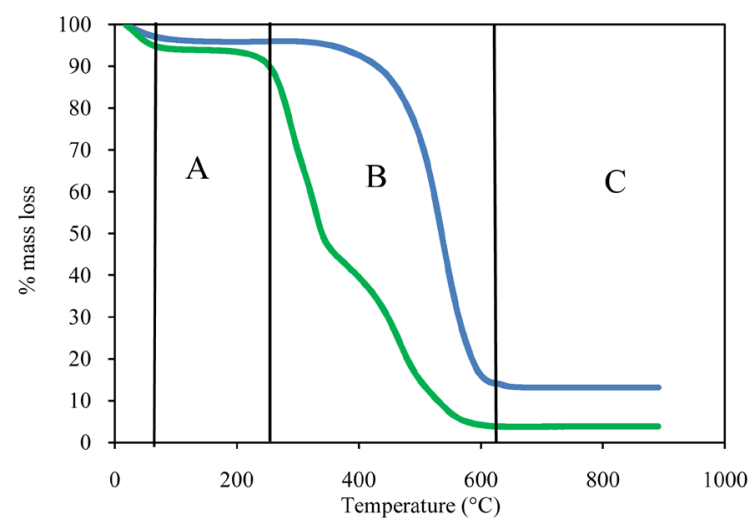

Figure 3. TG plots of coal and eucalyptus.

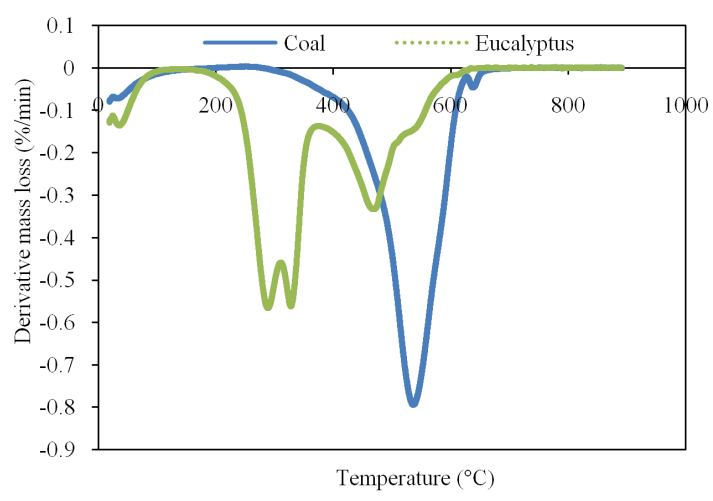

Figure 4. DTG plots of coal and eucalyptus. 


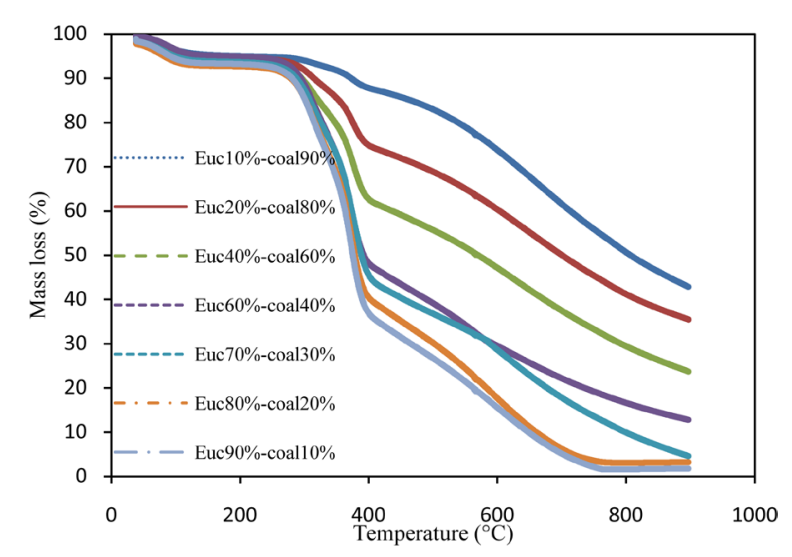

Figure 5. TG plots of the eucalyptus/coal blends.

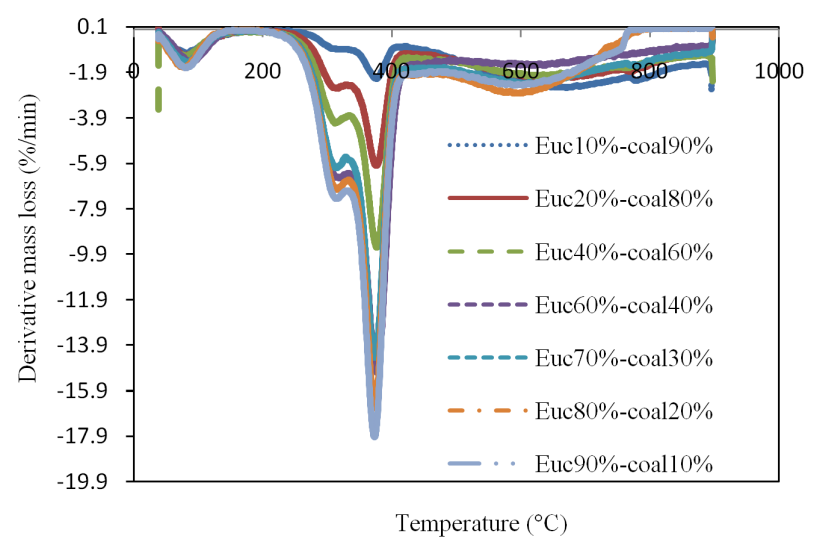

Figure 6. DTG plots of the eucalyptus/coal blends.

It is evident from Figure 5 that the addition of eucalyptus results in higher rate of devolatilization of the blend even at lower temperatures, the more the eucalyptus added to the blend the faster the reaction. The moisture content was observed to be almost the same for all the blends and the differences are clear in stage B where volatile matter is released and rapid devolatilization is taking place. This proves that there is a synergistic effect between coal and eucalyptus with eucalyptus acting as a catalyst for coal degradation due to its high volatile matter content, and the amount of ash left decreasing with the increase in the addition of eucalyptus. This therefore lowers the gasification temperature of the coal/biomass blend. Even Figure 6 shows that the euc ${ }_{90 \%}$-coal $_{10 \%}$ blend had the fastest degradation rate and euc $_{10 \%}-\mathrm{Coal}_{90 \%}$ had the slowest as previously stated, than the devolatilization of coal alone.

\subsection{ANOVA One Way Test}

Analysis of variance (ANOVA) is a general method that is used for studying sampled-data relationships. This method permits the difference between two or more sample means to be analyzed. Its purpose is to test for significant differences between means, and this is done by analyzing the variances. ANOVA was conducted on the TGA data. Table 4 shows the summary of the ANOVA one way test.

The $\mathrm{p}$ value was found to be $4.8477 \times 10^{-253}$, which is far less than 0.05 , therefore there is a significant difference between coal, eucalyptus and their blends, in terms of thermal degradation.

\section{Conclusion}

This study investigated the properties of the eucalyptus/coal blends and their suitability for co-gasification, with reference to pure eucalyptus and pure coal. The results suggested that blending biomass with coal result in an efficient clean energy with minimal negative impacts in the gasifier during co-gasification. Also, all the charac- 
Table 4. ANOVA one way test.

\begin{tabular}{|c|c|c|c|c|c|c|}
\hline Groups & Count & \multicolumn{2}{|c|}{ Sum } & \multicolumn{2}{|c|}{ Average } & Variance \\
\hline $100 \%$ coal & 5291 & \multicolumn{2}{|c|}{$324,928.8$} & \multicolumn{2}{|c|}{61.4116} & 1450.958 \\
\hline $100 \%$ euc & 2655 & \multicolumn{2}{|c|}{$202,252.9$} & \multicolumn{2}{|c|}{76.17812} & 559.9832 \\
\hline Euc $_{10 \%}$--coal $90 \%$ & 2655 & \multicolumn{2}{|c|}{$211,696.3$} & \multicolumn{2}{|c|}{79.73494} & 309.1994 \\
\hline Euc $_{20 \%}-$-coal $_{80 \%}$ & 2655 & \multicolumn{2}{|c|}{$191,909.1$} & \multicolumn{2}{|c|}{72.28214} & 448.6637 \\
\hline Euc $_{40 \%}-$-coal $_{60 \%}$ & 2655 & \multicolumn{2}{|c|}{$170,741.2$} & \multicolumn{2}{|c|}{64.30929} & 676.4141 \\
\hline Euc $_{60 \%}-$ - $)_{40 \%}$ & 1640 & \multicolumn{2}{|c|}{$125,490.8$} & \multicolumn{2}{|c|}{76.5188} & 584.7107 \\
\hline Euc $_{70 \%}-$-coal $_{30 \%}$ & 1640 & \multicolumn{2}{|c|}{$122,984.1$} & \multicolumn{2}{|c|}{74.99028} & 606.9891 \\
\hline 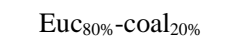 & 1640 & \multicolumn{2}{|c|}{$118,116.3$} & \multicolumn{2}{|c|}{72.02214} & 728.5802 \\
\hline Euc $_{90 \%}-$-coal $_{10 \%}$ & 1640 & \multicolumn{2}{|c|}{$116,588.7$} & \multicolumn{2}{|c|}{71.09069} & 828.5033 \\
\hline \multicolumn{7}{|l|}{ ANOVA } \\
\hline Source of Variation & SS & $d f$ & MS & $F$ & $P$-value & F crit \\
\hline Between Groups & $956,083.7$ & 8 & $119,510.5$ & 153.6287 & $4.8477 \times 10^{-253}$ & 1.938824 \\
\hline Within Groups & $17,473,589$ & 22,462 & 777.9178 & & & \\
\hline Total & $18,429,673$ & 22,470 & & & & \\
\hline
\end{tabular}

terization techniques suggested a strong existence of synergy between biomass and coal with biomass having a catalytic effect on coal during co-gasification, pyrolysis or combustion. The trace elements such as magnesium, aluminium, silicates and sulphur are then diluted when higher quantities of eucalyptus are present in the blends and this would reduce the risk of slagging during gasification of the material, which could be a challenge when coal is gasified alone.

\section{Acknowledgements}

This research was supported by the Fort Hare Institute of Technology and Eskom.

\section{References}

[1] Garcia, R., Pizarro, C., Lavin, A.G. and Bueno, J.L. (2012) Characterization of Spanish Biomass Wastes for Energy Use. Bioresource Technology, 103, 249-258. http://dx.doi.org/10.1016/j.biortech.2011.10.004

[2] Long, H.A. and Wang, T. (2011) Case Studies for Biomass/Coal Co-Gasification in IGCC Applications. Proceedings of ASME Turbo Expo, Vancouver.

[3] Shen, L.H., Gao, Y. and Xiao, J. (2008) Simulation of Hydrogen Production from Biomass Gasification in Interconnected Fluidized Beds. Biomass and Bioenergy, 32, 120-127. http://dx.doi.org/10.1016/j.biombioe.2007.08.002

[4] Brar J.S., Singh, K., Wang, J. and Kumar, S. (2012) Co-Gasification of Coal and Biomass-A Review. International Journal of Forestry Research. http://dx.doi.org/10.1155/2012/363058

[5] Pan, Y.G., Velo, E. and Puigjaner, L. (1996) Pyrolysis of Blends of Biomass with Poor Coals. Fuel, 75, 412-418. http://dx.doi.org/10.1016/0016-2361(95)00275-8

[6] Mamphweli, N.S. and Meyer, E.L. (2009) Implementation of the Biomass Gasification Project for Community Empowerment at Melani Village, Eastern Cape, South Africa. Renewable Energy, 34, 2923-2927. http://dx.doi.org/10.1016/j.renene.2009.06.011

[7] Ayhan, D. (2004) Combustion Characteristics of Different Biomass Fuels. Progress in Energy and Combustion Science, 30, 219-230. http://dx.doi.org/10.1016/j.pecs.2003.10.004

[8] Kumabe, K., Hanaoka, T., Fujimoto, S., Minowa, T. and Sakanishi, K. (2007) Co-Gasification of Woody Biomass and Coal with Air and Steam. Fuel, 86, 684-689. http://dx.doi.org/10.1016/j.fuel.2006.08.026 
Scientific Research Publishing (SCIRP) is one of the largest Open Access journal publishers. It is currently publishing more than 200 open access, online, peer-reviewed journals covering a wide range of academic disciplines. SCIRP serves the worldwide academic communities and contributes to the progress and application of science with its publication.

Other selected journals from SCIRP are listed as below. Submit your manuscript to us via either submit@scirp.org or Online Submission Portal.
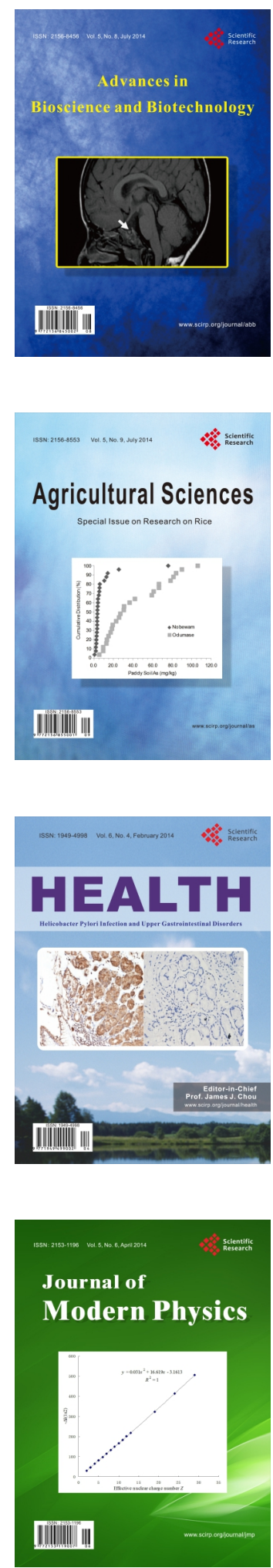
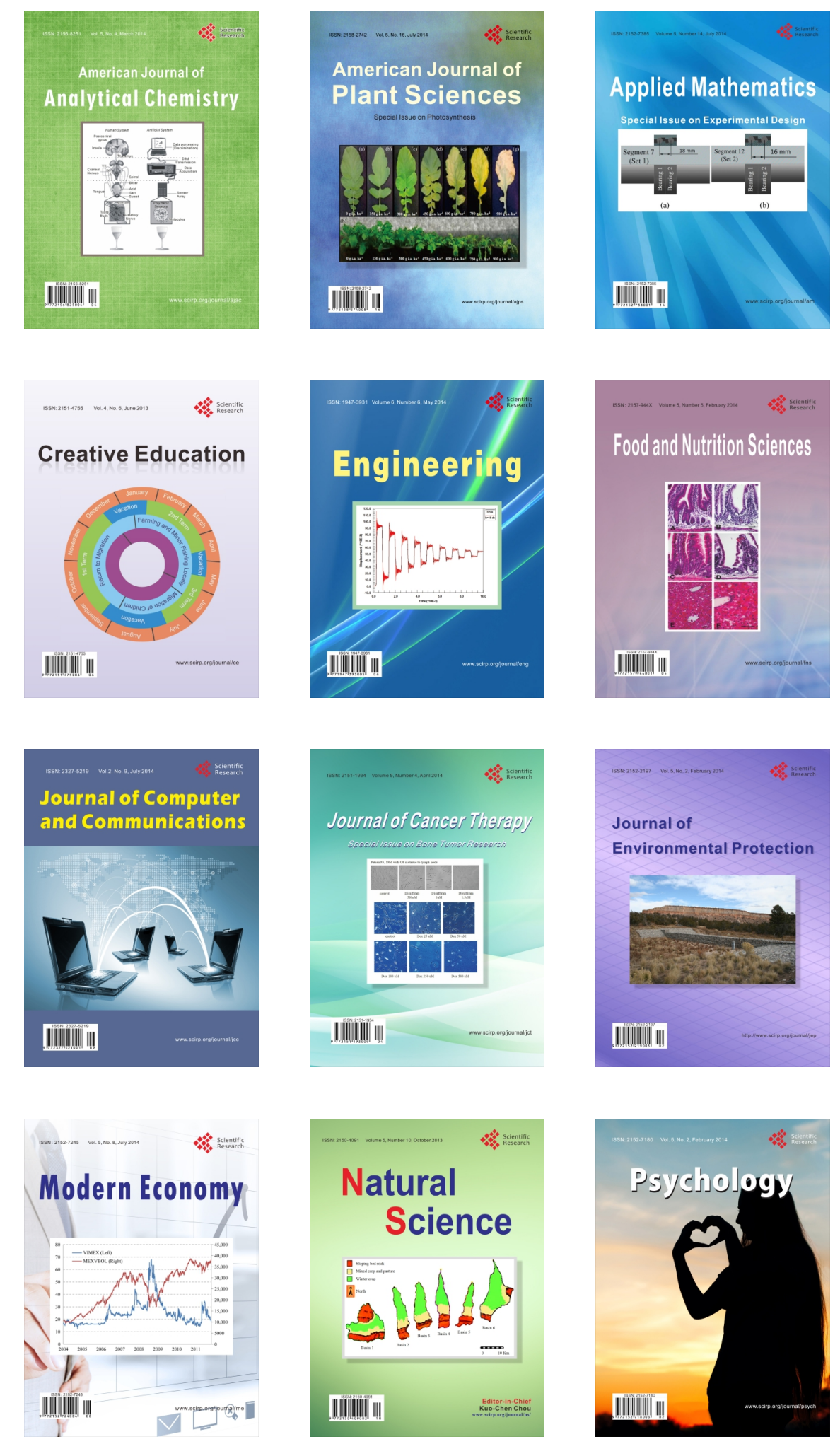